\title{
Lombok: Halal Tourism as a New Indonesia Tourism Strategy
}

\author{
Izza Firdausi ${ }^{1}$, Stanijuanita Marantika ${ }^{2}$, Zein Nidaulhaq Firdaus ${ }^{3}$, Rifqah Sajidah $^{4}$
}

\begin{abstract}
Since 2012 the Indonesian government has welcome tourism which had received attention and created high demand from foreign tourists originated from Islamic countries which is known as Halal Tourism. Realizing this potential, Indonesia introduced 12 provinces as halal tourism destinations and adopt some regulations to facilitate the implementation and execution of halal tourism. In 2015, Indonesia managed to get three awards in the World Halal Tourism Awards. The awards are for the 1st World's Best Halal Honeymoon Destination, the 1st World's Best Halal Tourism Destination, and the 1st World's Best Family Friendly Hotel. Lombok was awarded with two award categories and has become the foremost halal tourism destination in Indonesia.

This study examines Lombok as the foremost halal tourism destination in Indonesia is one of the strategy of the Indonesian government to branding its nation by using the concept of nation branding. Study literature was used to collect data about Lombok as a halal tourism destination in Indonesia, the intention of the Indonesian government to use halal tourism as a branding, and the impact of this branding towards the Indonesia nation branding.

The results of the research show that it is a strategy from Indonesian government to branding the nation through Halal Tourism Destination to attract more foreign tourists from Moslem populated countries like Middle East countries, Malaysia, Brunei Darussalam and other countries. Not only to attract foreign tourists but also to attract foreign investors to invest in Indonesia new tourism business sector. It is also to become the best Halal Tourism Destination in ASEAN.
\end{abstract}

Keywords - Halal Tourism, Nation Branding, Indonesia, Lombok.

\section{INTRODUCTION}

$\mathrm{T}$ HE Indonesian archipelago is rich in flora and fauna. The natural beauty of Indonesia become the main attraction for foreign tourists to visit Indonesia. The government realized the potential of Indonesia's tourism, but has not been supported by the development of its infrastructure and a good system to manage the tourism destination in Indonesia. Through several reforms undertaken by the Indonesian government, the Indonesian Ministry of Tourism is encouraged to maximize the potential of Indonesia tourism and added a function of the ministry to develop the creative economy sector. Tourism has become a major focus of Indonesian government to improve the economy. It can be seen in the statement from the President of Indonesia, Joko Widodo: "We must determine what will be the core of our economy, the core business of our country. Because by then we will be able to build our positioning. We can build our differentiation. We can build the brand of the State." (Yahya, 2017).

In 2012, the Government of Indonesia intends to introduce the Halal Tourism in Indonesia and on the next year, the government introduced the 12 destinations which are Moslem friendly destination. The 12 destinations are Aceh, West Sumatra, Riau, Lampung, Banten, Jakarta, West Java, Java east, Central Java, Yogyakarta, West Nusa Tenggara and South Sulawesi (Nirwandar, 2015: 10-11). The reason of this policy is the government realize that there is a new wave of tourism called Halal Tourism or Sharia Tourism which attracts a lot of foreign tourist from Moslem populated countries such as Saudi Arabia, Brunei Darussalam, Egypt, and much more. Furthermore, most of the population in the world is from Moslem populated countries and Indonesia as a country that has a lot of natural beauty along as the most Moslem populated country. So, it is a good business opportunity and it is prospected to be Indonesia biggest foreign exchange source in the future. Indonesia did not want to just be a market but also wants to be a producer of world halal tourism. For this reason, there is a question that will be discussed in this paper, which is 'how the Indonesian government's efforts to conduct halal tourism branding in Indonesia?', with a case study of the island of Lombok.

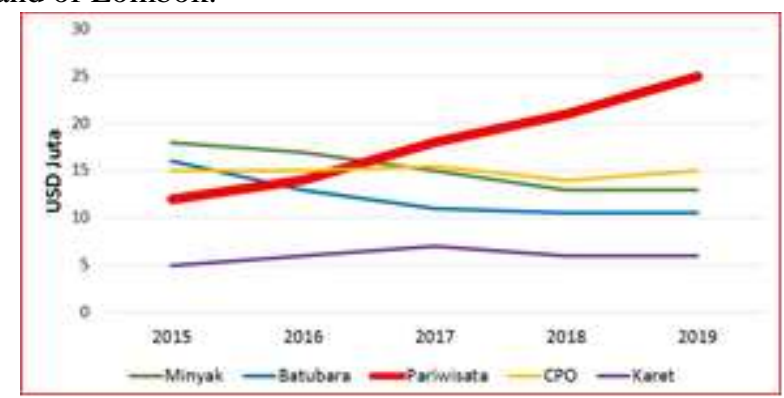

Fig. 1: "Graphic of Indonesia Tourism, prospected as the biggest Indonesia foreign exchange source"

(Ministry of Tourism of the Republic of Indonesia, 2017

To answer the research question, this paper will be divided into several parts. First, it will be discussed on the island of Lombok and the advantages of its natural tourist attractions; second, the concept of branding; third, the Indonesian government's strategy to build the image of Lombok as the foremost halal tourism destination in Indonesia; and the last is the result of the Lombok image building campaign 


\section{LOMBOK AS THE FOREMOST HALAL DESTINATION IN INDONESIA}

Lombok as one of the islands in Indonesia is well known for its natural attraction. There are several tourism sites we can find in Lombok. Some of them are coastal tourism, the beauty of Lombok's underwater, mountain climbing, and historical tour. Tourism site in Lombok is not less attracting than Bali which has been the most prominent destinations of Indonesian tourism. There are some attractive destinations in Lombok such as Senggigi Beach, Gili Trawangan and Rinjani Mountain.

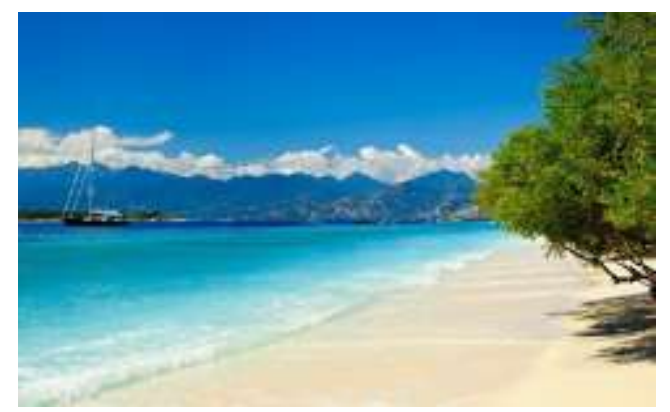

Fig. 2: "Picture of Senggigi Beach" (www.anekatempatwisata.com, 2015)

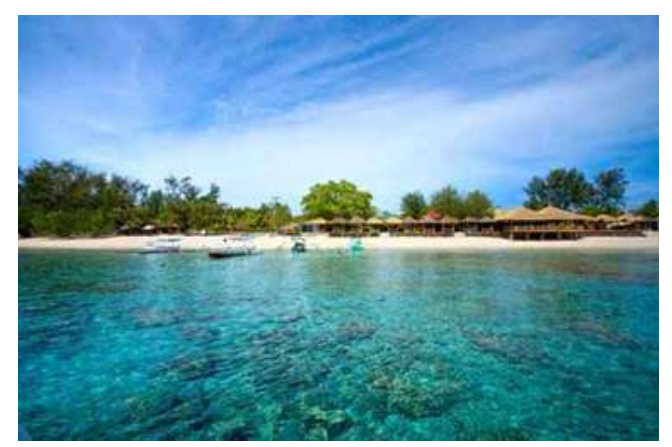

Fig .3: "Picture of Gili Trawangan" (www.lombokgilis.com, 2017)

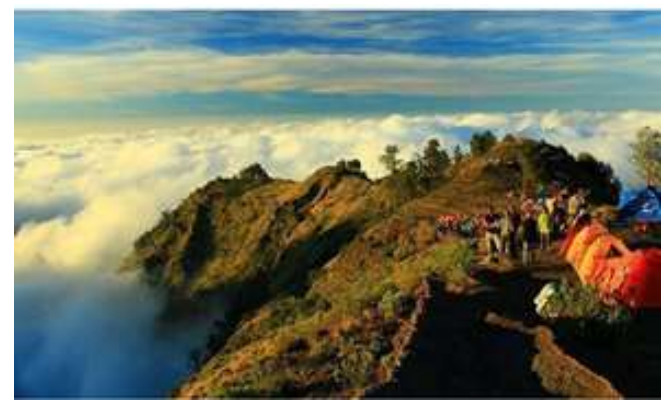

Fig. 4 : "Picture of Rinjani Mountain" (www.wonderfullomboksumbawa.com, 2016)

Indonesian government saw Lombok tourism potential and want to develop it towards halal tourism to attract more foreign tourists, especially Moslem populated countries. This effort is supported by the Indonesian government with the acceleration of development on the island of Lombok. The effort made Lombok in 2015 is awarded with two awards (the 1st World's Best Halal Honeymoon Destination and the 1st
World's Best Halal Tourism Destination) and two awards more in 2016 (the 1st World's Best Halal Honeymoon Destination and the 1st World's Best Halal Tourism Destination) from World Halal Tourism Award.

\section{NATION BRANDING}

Nation branding is an emerging phenomenon that is done by various countries. Nation branding can help improve the country's image and the results can be used for specific purposes. Keith Dinnie (2008), on the Nation Branding: Concepts, Issues, Practice, explained that the nation-branding is defined as the unique, multi-dimensional blend of elements that provide the nation with culturally grounded differentiation and relevance for all of its target audiences. Nation branding requires a combination of many elements to define branding as what they want and aimed at specific targets. A powerful and positive nation branding can provide a crucial competitive advantage to the country, especially in the arena of the global economy. Nation branding can attract foreign tourists, investors, entrepreneurs, and foreign consumers of a country's products and services (Dinnie, 2008: 15-18).

There are several components in nation-brand identity expressed by Dinnie, namely history, territory, sport, icons, folklore, and other things that are a representation of the state. In this research, the case studies of Lombok, which is one territory in Indonesia, become one of the components to see how the Indonesian nation branding efforts.

\section{Methodology}

The study of Lombok as one of Halal Tourism Destinations in Indonesia is carried out with the following steps: first, collect data about Lombok as a halal tourism destination in Indonesia from electronic media and official media of Lombok Tourism, collect data about the intention of Indonesian government to use halal tourism as a branding from journal publication, statistic data and Ministry of Tourism of the the Republic Indonesia's official website, and study literature for the nation branding concept.

\section{DESIGNING BRAND}

Branding the Lombok Island as halal tourism destination cannot be found in the form of pictures or logos. But there is one form of branding using an image only to call for voting at the World Halal Tourism Award 2016.

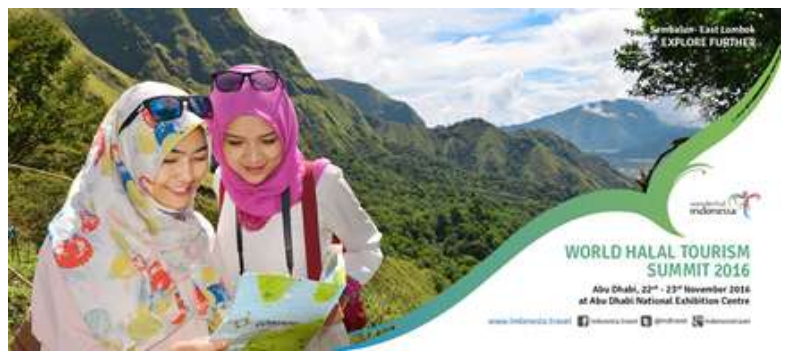

Fig .5: "Picture of Lombok Island Voting Campaign for World Halal Tourism Summit 2016" (www.indonesia.travel, 2015) 
There are two women who use hijab with Rinjani Mountain as the background in the picture. This picture shows the construction of Lombok Island image which is Moslem friendly tourism destination. The construction of this image is also supported by the majority of Moslem residents of Lombok Island. They upheld the friendliness and courtesy in Lombok. That supports the branding of Lombok Island as halal tourism destination. In addition, the nation branding efforts have been undertaken with the tagline 'Wonderful Indonesia' to describe all the natural beauty of Indonesia and other tourism places.

The purpose of this branding campaign is closely related to the urge of the Indonesian government through the Ministry of Tourism of the Republic of Indonesia to become the world's best halal tourism destination in 2019. This was stated by Minister Arief Yahya said in a press release to honor the best halal tourism awards in 2016, that "Indonesia is very potential to be the best halal tourism destinations in the world. Why? Because it has diversity of destinations and culture, and that is the main asset which is not owned by other countries. We are also increasingly confident in public awareness and national tourism industry to meet the need of Moslem travelers, sustainable tourism or Moslem friendly tourism" (Biro Hukum dan Komunikasi Publik, 2016).

5.1 Campaign Strategy with Focus on Increases Visibility and Credibility

Branding the Lombok Island as 'Halal Tourism Destination' are echoed by the various strategies. When we identify, the strategy is divided into internal and external strategy. Internal strategy was undertaken by the regional government of West Nusa Tenggara be addressed to local communities to improve the human resources and the service quality. The external strategy is the emphasis on the promotion and packaging appeal to the public. These strategies include:

1. Form the National Acceleration Team for Halal Tourism in Indonesia

2. Training from the Ministry of Tourism of the Republic of Indonesia to the local government residents in West Nusa Tenggara.

a. Tourist site Security Team (Pam Wisata) formation by involving local youth

b. Development assistance from the Ministry of Tourism of the Republic of Indonesia to build Middle East Culinary Centre in Mataram

c. Open up the center of souvenir shop in Senggigi Beach

3. Sustainable Development of Halal Tourism

a. Focus on the tourism development in Central Lombok, by Bappeda of Central Lombok

4. Achieve the goals to get the first rank in the Global Muslim Travel Index (GMTI) in 2017."

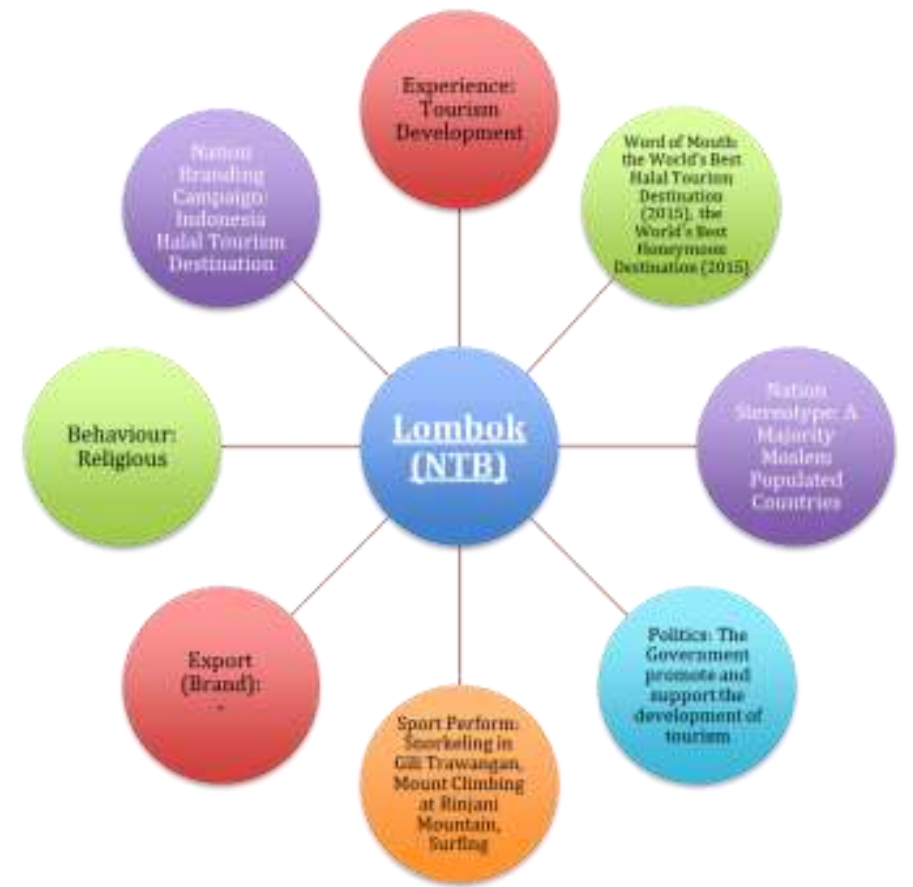

Fig .6: "Diagram of Lombok Island Image Formation Factors"

\section{CONCLUSION}

Lombok Island continues to promote its image through the social media and the tourism official website. As for tourism development, it is focused on halal tourism as mentioned above. The media strategy is balanced with government contacts with their locals and the community through several activities such as the establishment of Pam Wisata, training from the Ministry of Tourism of the Republic of Indonesia to the locals, and the development of tourism in the other area of West Nusa Tenggara.

Indonesia's efforts succeeded in increasing the number of foreign tourists who come to places with halal tourism concept, especially to Lombok (further review of the increased number of tourists can be seen on the official website of the Ministry of Tourism of the Republic of Indonesia). Not only that, in 2016, Indonesia won 12 awards in the World Halal Tourism Awards and ranked fourth. With the good acceleration in halal tourism sector in Indonesia, then Indonesia want to improve their performance in the arena of World Halal Tourism Awards because it will have a major impact on the Indonesia foreign exchange earnings.

\section{REFERENCES}

[1] A. Yahya. (2017, January 12). CEO Message \#18 Pariwisata sebagai Core Economy Negara. Retrieved $4^{\text {th }}$ of February, 2017, from the Ministry of Tourism of the Republic of Indonesia: http://kemenpar.go.id/asp/detil.asp?c=193\&id=3443

[2] Admin (2015, June 14). Pantai Senggigi, Bukti Keindahan Alam di Tanah Lombok. Retrieved $13^{\text {th }}$ of February, 2017, from the Aneka Tempat Wisata Web: http://anekatempatwisata.com/pantai-senggigibukti-keindahan-alam-di-tanah-lombok/

[3] Admin (2016, July 28). Gandeng Pemuda, Jaga Keamanan Pariwisata. Retrieved $11^{\text {th }}$ of February, 2017, from the Wonderful Lombok Sumbawa Web: http://wonderfullomboksumbawa.com/welcome/news_show/26

[4] Admin (2016, July 28). Lombok Tengah siap menjadi magnet bagi wisatawan. Retrieved $11^{\text {th }}$ of February, 2017, from the Wonderful 
Lombok

Sumbawa

http://wonderfullomboksumbawa.com/welcome/news_show/28

[5] Admin (2016, July 28). Pantai Eksotik yang Tersembunyi. Retrieved $11^{\text {th }}$ of February, 2017, from the Wonderful Lombok Sumbawa Web: http://wonderfullomboksumbawa.com/welcome/news_show/31

[6] Admin (2016, July 28). Pusat Kuliner Timur Tengah di Loang Baloq. Retrieved $11^{\text {th }}$ of February, 2017, from the Wonderful Lombok Sumbawa http://wonderfullomboksumbawa.com/welcome/news_show/35

[7] Admin (2016, July 28). Rinjani Menuju Geopark Dunia. Retrieved $11^{\text {th }}$ of February, 2017, from the Wonderful Lombok Sumbawa Web: http://wonderfullomboksumbawa.com/welcome/news_show/36

[8] Admin (2016, November 04). Alasan Ini Bisa Membuatmu Lebih Betah Tinggal di Sembalun. Retrieved $11^{\text {th }}$ of February, 2017, from the Wonderful Lombok Sumbawa Web: http://wonderfullomboksumbawa.com/welcome/news_show/42

[9] Admin (2016, November 04). Legong Siapkan Oleh-Oleh Khas NTB. Retrieved $11^{\text {th }}$ of February, 2017, from the Wonderful Lombok Sumbawa

http://wonderfullomboksumbawa.com/welcome/news_show/30

[10] Biro Hukum dan Komunikasi Publik. (2016, December 21). Siaran Pers Jumpa Pers Akhir Tahun 2016 Kemenpar siapkan program prioritas untuk mencapai target 15 juta wisman pada 2017. Retrieved $13^{\text {th }}$ of February, 2017, from the Ministry of Tourism of the Republic of Indonesia: http://www.kemenpar.go.id/asp/detil.asp?c=16\&id=3402

[11] Biro Hukum dan Komunikasi Publik. (2016, December 8). Indonesia Sapu Bersih 12 Kategori World Halal Tourism Award 2016. Retrieved $12^{\text {th }}$ of February, 2017, from the Ministry of Tourism of Republic of Indonesia: http://www.kemenpar.go.id/asp/detil.asp?c=16\&id=3393

[12] Biro Hukum dan Komunikasi Publik. (2016, September 21). Siaran Pers Anugerah Pariwisata Halal Terbaik 2016. Retrieved $13^{\text {th }}$ of February, 2017, from the Ministry of Tourism of the Republic of Indonesia: http://www.kemenpar.go.id/asp/detil.asp?c=16\&id=3310

[13] C. Nunns. (2015, August 1). Lombok bids to attract tourists - but keep the island green. Retrieved $30^{\text {th }}$ of January, 2017, from the Guardian: https://www.theguardian.com/travel/2015/aug/01/lombok-indonesiabali-eco-tourism-development

[14] CNN Indonesia (2016, August 28). Tim Percepatan Wisata Halal Sukses Saring Ratusan Kontestan. Retrieved $13^{\text {th }}$ of February, 2017, from the CNN Indonesia Web: http://www.cnnindonesia.com/gayahidup/20160828212044-307-154365/tim-percepatan-wisata-halalsukses-saring-ratusan-kontestan/

[15] F. Muslimah (2016, August 23). Inilah Strategi Kemenpar Untuk Jadikan Wisata Halal Indonesia Terbaik di ASEAN. Retrieved $13^{\text {th }}$ of February, 2017, from the Go Muslim Web: http://www.gomuslim.co.id/read/news/2016/08/23/1265/inilah-strategikemenpar-untuk-jadikan-wisata-halal-indonesia-terbaik-di-asean.html

[16] Jackysan (2016, October). Horeee, Lombok Memenangi 4 Kategori di Kompetisi Wisata Halal Nasional 2016. Retrieved $13^{\text {th }}$ of February, 2017, from the Holiday is Lombok Web: https://www.holidayislombok.com/lombok-memenangi-kompetisiwisata-halal-nasional-2016.html

[17] K. Dinnie, Nation Branding, 1st ed. Burlington, USA: ButterworthHeinemann, 2008, ch. 2, pp. 60-80.

[18] K. G. Widagdyo. (2015). Analisis Pasar Pariwisata Halal Indonesia. The Journal of Tauhidinomics [Online]. 1(1). pp. 1-19. Available: https://mpra.ub.uni-muenchen.de/76235/

[19] K. Yustiana (2016, August 26). Lombok Siapkan Wisata Pantai Ramah Muslim. Retrieved $13^{\text {th }}$ of February, 2017, from the Detik Travel Web: https://travel.detik.com/read/2016/08/26/072547/3283992/1382/lombo k-siapkan-wisata-pantai-ramah-muslim

[20] Ministry of Tourism, the Republic of Indonesia (2014). Rencana Strategis: Pengembangan Destinasi dan Industri Pariwisata Tahun 2015-2019. Retrieved $12^{\text {th }}$ of February, 2017, from the Ministry of Tourism Web: http://www.kemenpar.go.id/userfiles/Renstra\%20Deputi\%20PDIP_3_0 \%20versi\%20pdf.pdf

[21] Ministry of Tourism, the Republic of Indonesia (2015, August 15). Perkembangan Wisatawan Mancanegara Menurut Pintu. Retrieved $10^{\text {th }}$ of February, 2017, from the Ministry of Tourism Web: http://kemenpar.go.id/asp/detil.asp?c=110\&id=1410

[22] Ministry of Tourism, the Republic of Indonesia (2015, October 1). Pesona Magazine: New Wave Moslem Tourism. Retrieved $10^{\text {th }}$ of February, 2017, from the Ministry of Tourism Web: http://kemenpar.go.id/asp/ringkasan.asp?c=162
[23] Ministry of Tourism, the Republic of Indonesia (2016, December 1). Data Kunjungan Wisatawan Mancanegara tahun 2016. Retrieved $10^{\text {th }}$ of February, 2017, from the Ministry of Tourism Web: http://kemenpar.go.id/asp/detil.asp?c=110\&id=3139

[24] Ministry of Tourism, the Republic of Indonesia (2016, December 8). Indonesia Dominates World Halal Tourism Awards 2016 Winning 12 Top Categories. Retrieved $13^{\text {th }}$ of February, 2017, from the Ministry of Tourism Web: http://www.indonesia.travel/en/post/indonesiadominates-world-halal-tourism-awards-2016-winning-12-topcategories

[25] Ministry of Tourism, the Republic of Indonesia (2016, January 1). Data Kunjungan Wisatawan Mancanegara tahun 2015. Retrieved $10^{\text {th }}$ of February, 2017, from the Ministry of Tourism Web: http://kemenpar.go.id/asp/detil.asp?c=110\&id=2854

[26] PT. Indonesia Tropic Holiday \& Cruises (n.d.). Paket Wisata Snorkeling Gili Trawangan and Gili Meno. Retrieved $13^{\text {th }}$ of February, 2017, from the Lombok Gilis Web: http://www.lombokgilis.com/paket-wisata-lombok/paket-wisataharian/103-paket-wisata-snorkeling-gili-trawangan-dan-lombok.html

[27] R. J. Vidmar. (August 1992). Halal tourism industry in Indonesia: Potential and prospects. MPRA Munich Personal RePEc Archive [Online]. No. 76235. pp. 1-19. Available: https://mpra.ub.unimuenchen.de/76235/

[28] Redaksi Lombok Post (2016, October 8). Kejar Destinasi Utama Wisata Halal Dunia, NTB Menang Empat Kategori. Retrieved $12^{\text {th }}$ of February, 2017, from the Lombok Post Web: http://www.lombokpost.net/2016/10/08/kejar-destinasi-utama-wisatahalal-dunia/

[29] Redaksi Tempo (2016, September 25). In 2019, Tourism to be Indonesia Biggest Foreign Exchange Source. Retrieved $12^{\text {th }}$ of February, 2017, from the Tempo Web: https://en.tempo.co/read/news/2016/09/25/056807155/In-2019Tourism-to-be-Indonesia-Biggest-Foreign-Exchange-Source

[30] S. Nirwandar, "Halal Lifestyle in Indonesia," presented at the UNWTO Seminars, Brunei Darussalam, November $16^{\text {th }}, 2015$. 


\title{
The Analysis of Indonesia Cultural Diplomacy Through Angklung In Strengthening National Identity
}

\author{
Stanijuanita Marantika ${ }^{1}$,Izza Firdausi ${ }^{2}$, Zein Nidaulhaq Firdaus ${ }^{3}$, Rifqah Sajidah $^{4}$
}

\begin{abstract}
Indonesia is the multicultural country. There are many differences and diversity that Indonesia has as language, race, tribe, religion even culture. Instead of becoming Indonesia heritage, it also becomes crack for the unity if the governance cannot supervise it with well maintain. One of the examples is Angklung that was ever claimed by Malaysia. It gives a lot of protests from Indonesia citizens and evaluation for Indonesia to maintain more the culture that Indonesia has. That moment proves how valuable Angklung is. According to Unesco, Angklung is an Indonesian musical instrument consisting of two to four bamboo tubes suspended in a bamboo frame, bound with rattan cords. The purpose of this research is to identify how Angklung can be one of soft power that strengthens national identity Indonesia. Study literature and interviews were used to collect data about this research. Then explains and describes the efforts made by the government as a form of cultural diplomacy to promote Indonesia to the world through Angklung.
\end{abstract}

Keywords - Angklung, Art, Cultural Diplomacy, Indonesia, National Identity.

\section{INTRODUCTION}

The Indonesian archipelago is the richness of culture, has population 243 million and the area is 1.9 million sq $\mathrm{km}$ (742,308 sq miles), major languages Indonesia is Indonesian while there are a lot local languages, race, tribe religion even culture. Then angklung is one the wonderful heritage that Indonesia has. Angklung initially emerged as a form of religious ritual. Its main function is to invite Dewi Sri, the Goddess of Rice to come to earth to give a blessing on the earth and fertility fot the plants. While the forms of angklung has a philosophy where each tube is likened to a man's relationship with other humans. Different size of each tube means that everyone has a different way to create harmony in the world. The word Angklung originated from two words angka and lung. Angka means "tone", and lung means "broken" or "lost". Angklung then means as an incomplete tone [1].

According to experts, the traditional music of the Universitas of Pasundan (Unpas) Rosikin in Bandung, although angklung is a traditional music instrument because of the flexiblity music instrument it can follow the development of the world. Angklung has a dual function, first the pentatonic music is the original tone of the Sundanese songs

Stanijuanita Marantika ${ }^{1}$,Izza Firdausi ${ }^{2}$, Zein Nidaulhaq Firdaus ${ }^{3}$, Rifq Sajidah4Universitas Padjadjaran ${ }^{2}$, Universitas Padjadjaran, Universitas Padjadjaran $^{4}$ but can also be developed with diatonic music that is widely used by Western music. In addition to flexible, angklung is also a means of traditional music which is very easy to play. For those who never learn angklung, can immediately understand how to play it in just a few minutes. Amazingly one person can play at the same pitch four octaves.

The oldest angklung still exist is called Angklung Gubrag. The angklung was made in the 17th century in Jasinga, Bogor. Nowadays, some of reviews those older Angklung Werner in Sri Bduga Museum, Bandung [2]. Then in 1938, Daeng Soetigna make diatonic tones of angklung more often used to play with western songs rather than traditional tones. Since that time the angklung is used for education and entertainment. The first time, angklung performances get the world's attention is when the Asia Africa Conference in the year 1955. Following the struggle Daeng Seotigna, her student Udjo's wife, collaborated with her husband thereby opening the House of Angklung or Saung Angklung -as we called it- in Bandung.

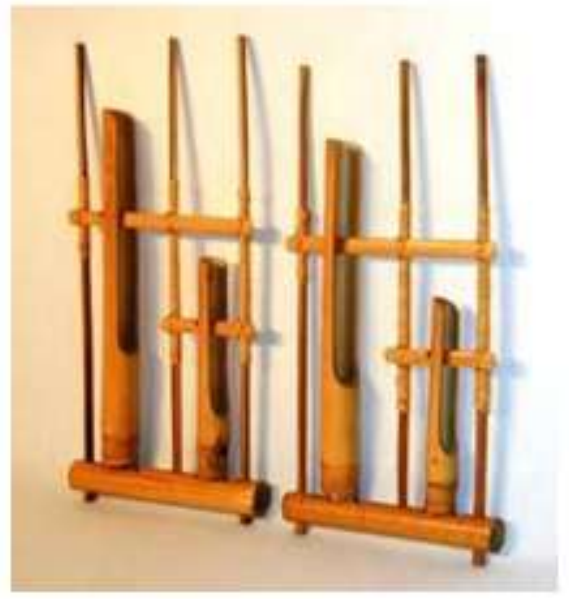

Fig.1: Angklung(mannaismayaadventure.com,2011) 